IN MEMORIAM

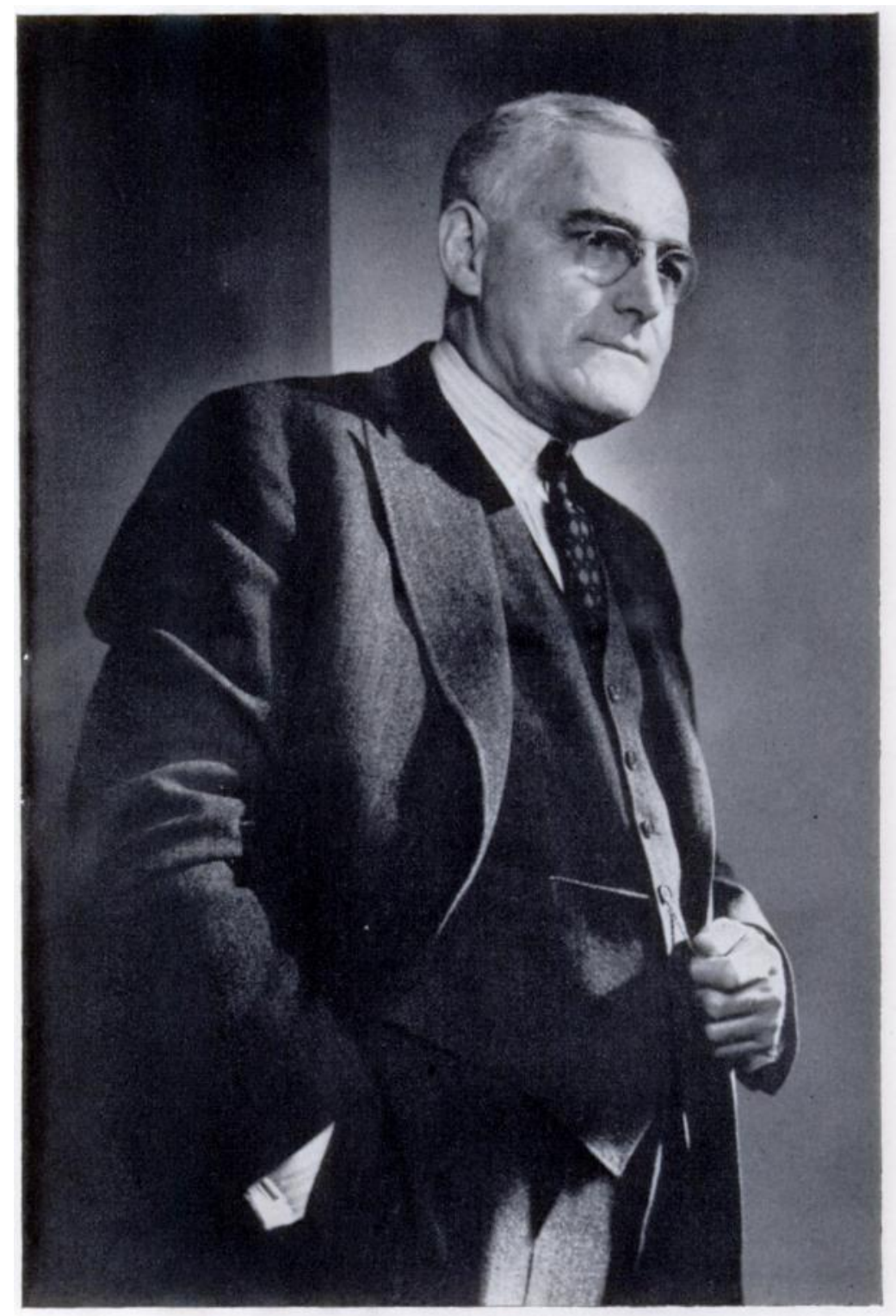




\section{WILLIAM EDWARD GALLIE}

1882-1959

On Monday. September 28, 1959, the University paid homage for the last time to William Edward Gallie. Emeritus Professor of Surgery of the University of Toronto. The sadness at his death was felt far beyond the confines of the University. It permeated the great societies of surgery and the hearts of surgeons throughout the world. Few men have been so esteemed.

Few have been so richly honoured. The Royal College of Surgeons of England awarded him its highest order of merit-the Gold Medal of the College. In company with His Royal Highness the Duke of Edinburgh he received an Honorary Fellowship of the Royal College of Surgeons of Edinburgh. He was a Founding Fellow of the Royal College of Surgeons of Canada. The United States of America held him in equal regard. He was President of the American Surgical Association, and of the American Orthopaedic Association. He occupied the Presidency of the American College of Surgeons for five years. In these offices he exerted a wise and powerful influence upon the schools of surgery in North America. At home Professor Gallie was a dominant person. He became, at the age of thirty-nine, an Associate Professor of Surgery and Chief of the Division of Surgery of the Toronto Hospital for Sick Children. Eight years later he was appointed Professor of Surgery and Surgeon-inChief of the Toronto General Hospital. Before and during the difficult years of the second world war he carried an additional responsibility as Dean of the Faculty of Medicine. Learned scientific contribution, wise policy and, above all, a profound dedication to the practice of surgery summoned the approbation of his peers.

Edward Gallie was a man of great stature and comprehension. He could dominate most gatherings both physically and mentally, yet he was never a bully. On the contrary, the warmth of his personality was radiant. He was the best of friends. He captured his colleagues by exhibiting a tactful curiosity in their welfare and assumed that they were equally engrossed in him. Conversation with him became a temporary partnership. He was gentle. Those who might well have entertained some fear, by reason of his size or position, soon became easy companions or devoted followers. He charmed his rivals into an agreement or a truce. Differences of opinion in others were respected but were not allowed to mature into ill-feeling which he abhorred. Anger came slowly and was reserved for a contemptible few who transgressed his sense of honesty or who followed unethical practices.

He possessed an unexcelled joy of living. Somehow, daily contact with people supplied him with fuel to maintain this enthusiasm. Boredom and drudgery were unknown. He was rescued from these by a magnificent sense of humour. Laughter came easily and in great gusts. He enjoyed laughing and laughed as quickly at himself as at others. This asset was carefully directed. He seldom hurt anyone, yet often the most dismal ward rounds were saved from disaster by the quick wit of the professor.

He was a virile man, a natural athlete. His first great love was hockey. He won his spurs with the team of the Barrie Grammar School in the town where he was born. As an undergraduate medical student, he played for the University of Toronto, and when he could no longer play he coached the University team for five years. War intervened, and on his return from England he turned his attention to golf. It is significant that the home he built and lived in until he died borders on and looks across the rolling hills of the Rosedale Golf Club. Somewhere with the advance of time, golf palled and he became a rabid fisherman, to the exclusion of all other sport. Latterly his visits to the trout streams of Quebec and the salmon rivers of New Brunswick were in constant competition with an ankle fusion or a

VOL. 41 B. NO. 4, NOVEMBER 1959 
recurring dislocation of the shoulder, and it was as much as the life of the resident was worth for him to suggest which was the more important.

The talents of this great man were devoted to the development of surgery in Canada. He taught himself first. His clinical disputes were resolved in the experimental laboratory. No one has challenged his conclusions with regard to the grafting of bone and the transplantation of fascia as a living suture. His operative procedures contain the germ of simplicity and have stood the test of experience.

He brought to the Professorship a purpose. Though by inclination an orthopaedic surgeon, he realised that the need of the country for capable general surgeons far outweighed the necessity of training men in surgical specialities. Pursuing this vision with vigour, he established for the first time in Canada an organised training course for surgeons. The Gallie course was designed to produce in the trainee a thorough knowledge of the art, a sense of responsibility to the patient and an enquiring mind. The Professor insisted that the master surgeon should assist the pupil. Acquired skill gradually slackened the reins of supervision. Towards the completion of the course came a period of glorious association with the Chief. As senior resident, the budding surgeon was encouraged to take sole charge of cases, trusted by $\mathrm{Dr}$ Gallie to seek advice if he were in doubt.

He satisfied a hunger for continuing education by a close association with the learned societies of the United States of America and of Great Britain. He repeatedly spoke of the pleasant periods of companionship that he enjoyed with the leading surgeons of the world, and he would return to the hospital stimulated by their influence. Young Canadians were encouraged to seek membership in such associations and to proffer to them the results of their own surgical endeavours.

At Dr Gallie's funeral, in the midst of the great assembly, fifty-two surgeons, members of the Gallie Club, stood together. They had graduated from the Gallie Training Course in Surgery during his active Professorship. Now middle-aged, they are senior surgeons of several North American hospitals. Many are chiefs of the surgical staff; fourteen are assistant or associate Professors of Surgery; and four are full Professors. These men represent Dr Gallie's living suture of surgeons.

On a memorable occasion twelve years ago they heard their Chief express this hope for his years in retirement. He envisaged himself as the slowly setting sun of the Arctic-lingering on the horizon until it was imperceptibly absorbed into the distant future. The Gallie slaves were glad that their Chief had been granted his wish.

F. P. D.

\section{ARTHUR STEINDLER}

1878-1959

Between the end of the American civil war and the outbreak of the first world war one of the greatest migrations in modern times took place. Some fifteen million people passed through " the golden door " into the United States. Among the hundreds of thousands from the old Hapsburg Empire was a young Viennese doctor, Arthur Steindler. He arrived in 1907 at the age of twenty-nine, settled in the middle west, first in Chicago, then in Des Moines and finally in lowa City. If he had practised competently and earned a decent living he would have done well enough; as it turned out, this man, in an environment remote from venerable centres of learning. came to occupy a unique position. He became the pre-eminent scholar of orthopaedics not only in North America but in the world. 